\title{
Reevaluating the age and tectonic implication of the Karamay Ophiolitic mélange, Northwest China
}

\author{
QINYAN WANG ${ }^{1 *}$, BINGXIU SU ${ }^{2}$, YIXIAN XU ${ }^{1}$, XIAOWEI \\ $\mathrm{GUO}^{2}$, NAIXIAO XU ${ }^{3}$ \\ ${ }^{1}$ School of Earth Sciences, Zhejiang University, 310027 , \\ Hangzhou, China \\ ${ }^{2}$ School of Earth Sciences, China University of Geosciences, \\ 430074, Wuhan, China \\ ${ }^{3}$ School of Ocean and Earth Science, Tongji University, \\ 200092, Shanghai, China
}

The Western Junggar of Xinjiang, NW China, located in the southwestern part of the Central Asian Orogenic Belt (CAOB), has been considered as a key place to reconstruct the subduction and accretion processes during the closure of Paleo-Asian Ocean. Karamay ophiolitic mélange is the major and the youngest among several NE-SW oriented accretionary complex zones in Western Junggar. However, its ages had been dated ranging from Cambrian to Carboniferous, causing a long-term debate on its formation in tectonics.

Samples collected from Baijiantan and Baikouquan in Karamay mélange show a complete ophiolitic series, including ultramafic-mafic rocks, pillow basalts and abyssal siliceous rocks. Ultramafic-mafic rocks contain spinel harzburgite, lherzolite, gabbro, amphibole pyroxenite, and hornblendite. The geochemical characteristics suggest that they were derived from depleted mantle with slight fluidenrichment, resulted from the mantle upwelling about ca. 364 $\mathrm{Ma}$ ago, or from the partial melting residues of enriched to weakly depleted lithospheric mantle. The mafic rocks (gabbro, amphibole pyroxenite, etc.) have been dated ranging from 346 to $311 \mathrm{Ma}$ with source very similar to peridotite. Accordingly, we propose that they were formed by further crystallized differentiation of upwelling mantle melts. After the formation of peridotite, a small amount of early Paleozoic or even more ancient mantle source material was involved in diagenetic process, caused by fluid or melt addition from the subduction. The amphibole pyroxenite and hornblendite are indicatives of the ophiolitic mélange related to subduction. Zircon U-Pb dating combined with Hf isotopic chronology from the mafic rocks constrain that the formation age of the abyssal peridotites is about 364 to $346 \mathrm{Ma}$, and Karamay ophiolitic assemblages should be emplaced in 364 to $311 \mathrm{Ma}$, indicating that the Paleo-Asian Ocean remains unclosed until the late carboniferous or even later. Our data also decipher that Karamay ophiolitic complex contains the components of MOR-related subduction.

The study is supported by NSFC with grant 41530319 . 